\title{
Structural and magnetic characterization of $(\mathrm{Ba}, \mathrm{Sr})$-hexaferrite powders ${ }^{(\cdot)}$
}

\author{
S. Palomares-Sánchez ${ }^{(*)}$, S. Ponce-Castañeda $(*)$, F. Ruiz ${ }^{(*)}$, \\ M. Mirabal-García $\left.{ }^{*}\right)$ J. R. Martínez ${ }^{(* *)}$ and S. Díaz-Castañón ${ }^{(* * *)}$
}

\begin{abstract}
Results on magnetic and structural characterization of ferrimagnetic compounds of $\mathrm{Ba}_{\mathrm{x}} \mathrm{Sr}_{1-\mathrm{x}} \mathrm{Fe}_{12} \mathrm{O}_{19}(\mathrm{x}=0.0,0.25,0.50,0.75$ and 1.0) prepared by the conventional ceramic method are reported. The samples were systematically examined using atomic force microscopy (AFM), X-ray diffraction and vibrating sample magnetometer. Structural and magnetic differences among the specimens were observed. The relations between structural features and magnetic properties are discussed. The presintering temperatures of the samples were $800^{\circ} \mathrm{C}$ and $1,000^{\circ} \mathrm{C}$. The specimens were sintered at $1,200^{\circ} \mathrm{C}$ for one hour.
\end{abstract}

Keywords: Ferrites. Ceramics. Magnetic properties. Atomic force microscopy.

\section{Caracterización magnética y estructural de hexaferritas de (Ba,Sr)}

\begin{abstract}
Resumen Se presentan resultados de la caracterización estructural y magnética de compuestos ferrimagnéticos $\mathrm{Ba}_{\mathrm{x}} \mathrm{Sr}_{1-\mathrm{x}} \mathrm{Fe}_{12} \mathrm{O}_{19}(\mathrm{x}=0,0,0,25,0,50,0,75$ y 1,0$)$ preparados por el método cerámico convencional. Las muestras fueron examinadas por microscopía de fuerza atómica, difracción de rayos X y magnetometría de muestra vibrante. Se observaron diferencias tanto estructurales como magnéticas en las muestras analizadas. Se discuten las relaciones entre los aspectos estructurales y los parámetros magnéticos medidos. Las temperaturas de presinterización de las muestras fueron de $800^{\circ} \mathrm{C}$ y $1.000^{\circ} \mathrm{C}$ y fueron sinterizadas a $1.200^{\circ} \mathrm{C}$ durante una hora.
\end{abstract}

Palabras clave: Ferritas. Cerámicos. Propiedades magnéticas. Microscopía de fuerza atómica.

\section{INTRODUCTION}

A group of iron oxide materials named Ferrites with the formula $\mathrm{MO} \cdot 6 \mathrm{Fe}_{2} \mathrm{O}_{3}$, where $\mathrm{M}$ is one or more of the divalent metals $\mathrm{Ba}, \mathrm{Sr}$ and $\mathrm{Pb}$, is one of the most commercial magnetic materials produced. Substitution ferrites, where Co-Ti or Co-Sn substitutes some iron, have received much attention due to their potential application as high-density magnetic storage systems (1). Also they have been

(•) Trabajo recibido el día 20 de abril de 1998. Nueva versión enviada por los autores el día 20 de septiembre de 1998 y aceptado en su forma final el día 20 de abril de 1999.

(*) Instituto de Física, "Manuel Sandoval Vallarta", Universidad Autónoma de San Luis Potosí, 78000 San Luis Potosí, S.L.P. (México).

(**) Facultad de Ciencias, Universidad Autónoma de San Luis Potosí 78000 San Luis Potosí, S.L.P. (México).

(***) Lab. de Magnetismo, Facultad de Física-IMRE, Universidad de la Habana, La Habana (Cuba). extensively used as permanent magnets and microwave devices because of their large intrinsic uniaxial anisotropy and their high coercivity (2).

This kind of materials can be prepared using various techniques (3-10). The technique of preparation determines the magnetic properties of the samples and therefore discrepancies have been observed in the values of the magnetic parameters when different preparation techniques are used (11). Also, several studies were made on samples with the composition $(\mathrm{BaO})_{0.75}(\mathrm{SrO})_{0.256} \mathrm{Fe}_{2} \mathrm{O}_{3}$ with addition of group III oxides (12), on single crystal of mixed $\mathrm{Ba}-\mathrm{Sr}$ ferrites as single crystal (13) and on samples prepared with the self propagating high temperature synthesis method (SHS) (14). To optimize hard ferrites for permanent magnet applications, a compromise is usually assumed between a high value of remanence or a high coercivity. The remanence is a strong function of density, chemistry, and orientation, while the coercive force is dependent on microstructural features, and thus related with the grain size (15). 

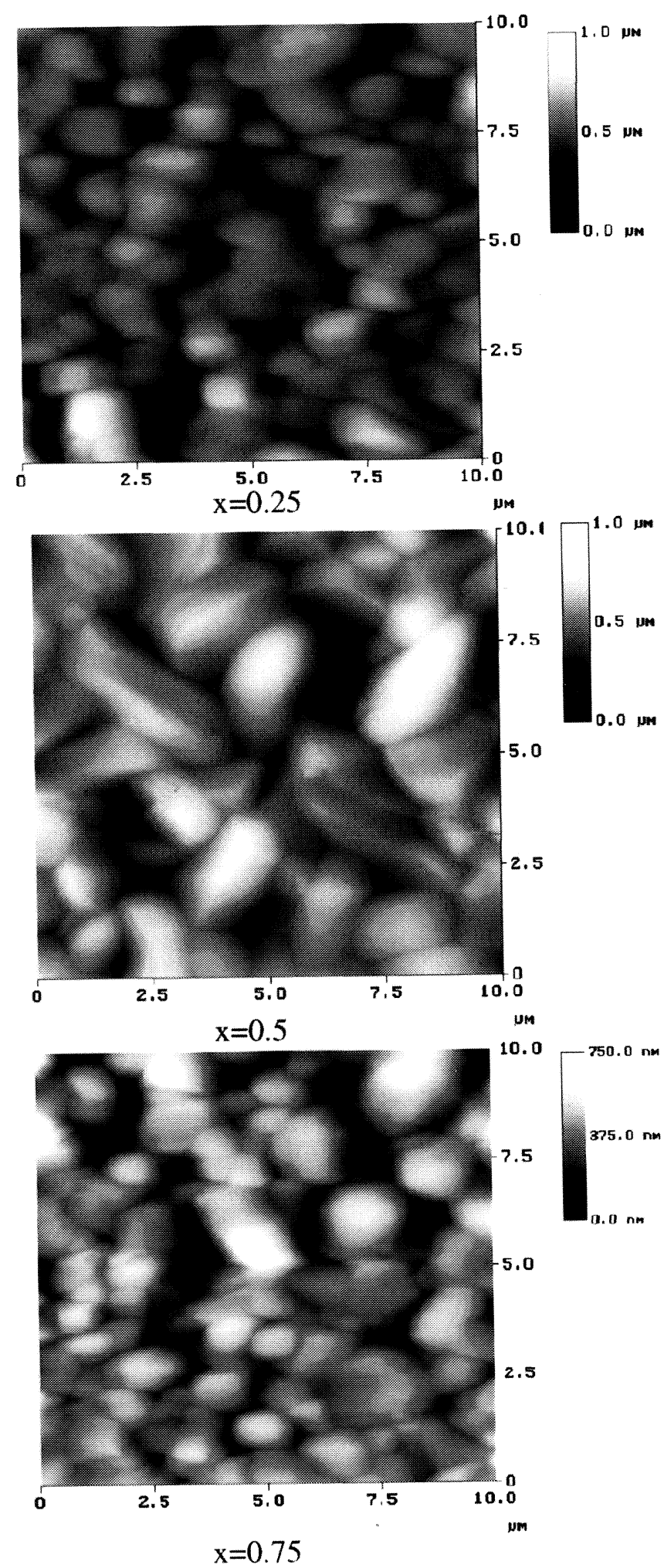

In this work the influence of the microstructural features of the grain for different concentration of $\mathrm{Ba}$ and $\mathrm{Sr}$ in samples of $\mathrm{Ba}_{x} \mathrm{Sr}_{1-x} \mathrm{Fe}_{12} \mathrm{O}_{19}$ over the coercive force is studied. Results of surface characterization in samples prepared by the conventional ceramic method with different concentrations of $\mathrm{Ba}$ and $\mathrm{Sr}$ using an atomic force microscope, AFM (16) are presented. AFM is able to

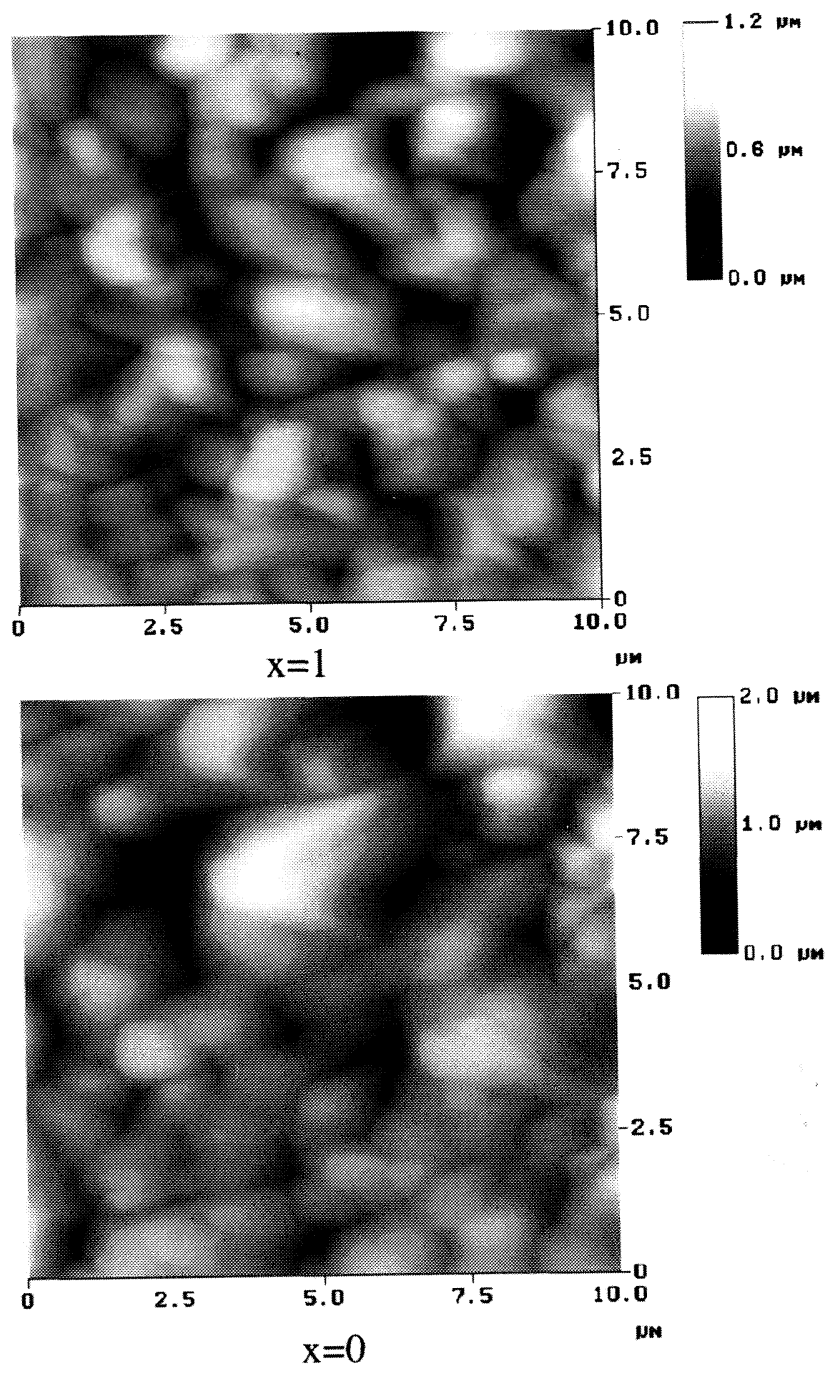

FIG. 1.- AFM images for samples with $\mathrm{x}=0.0$, $x=0.25, x=0.50, x=0.75$ and $x=1.0$, with the same presintering and sintering temperatures, $1,000{ }^{\circ} \mathrm{C}$ and $1,200{ }^{\circ} \mathrm{C}$, respectively.

FIG. 1.- Imágenes de MFA para muestras con $x=0.0, x=0,25, x=0,50, x=0,75$ y $x=1,0$, preparadas a las mismas temperaturas de presinterización y de sinterización, $1.000^{\circ} \mathrm{C} y$ $1.200{ }^{\circ} \mathrm{C}$, respectivamente.

provide information about microstructural characteristics of the surface that might be correlated with the formation or growing parameters of the researched materials. These results are complemented with X-ray patterns of the samples. Magnetic characterization was performed using a vibrating sample magnetometer (VSM) in order to obtain coercivity $(\mathrm{iHc})$ and saturation magnetization $\left(\sigma_{\mathrm{s}}\right)$. 


\section{EXPERIMENTAL PROCEDURE}

( $\mathrm{Ba}, \mathrm{Sr}$ )-M type ferrites were prepared by the ceramic method. In order to produce ferrites by this method the basic powders $\mathrm{BaCO}_{3}, \mathrm{SrCO}_{3}$ and $\mathrm{Fe}_{2} \mathrm{CO}_{3}$ were mixed stoiquiometrically to obtain $\mathrm{Ba}_{\mathrm{x}} \mathrm{Sr}_{1-\mathrm{x}} \mathrm{Fe}_{12} \mathrm{O}_{19},(\mathrm{x}=0.0,0.25,0.50,0.75$ and 1.0). High purity powders from Strem Chemicals were used. In the preparation of the specimens, all the constituent oxide powders were mixed homogeneously by ball milling in ethanol for two hours. After this, the resulting mixture was ground in air using also a silicon nitride mortar in order to reduce the particle size. Powders were presintered at $800{ }^{\circ} \mathrm{C}$ or $1,000{ }^{\circ} \mathrm{C}$ during $2.75 \mathrm{~h}$. A heating rate of $550{ }^{\circ} \mathrm{C} / \mathrm{h}$ was used. Polyvinyl alcohol was used as a binder and samples of different sizes were pressed as discs by applying a pressure of $35 \mathrm{MPa}$. For the sintering process the samples were heated at $300{ }^{\circ} \mathrm{C}$ $/ \mathrm{h}$, hold at $600{ }^{\circ} \mathrm{C}$ during one hour and finally heated at $300{ }^{\circ} \mathrm{C} / \mathrm{h}$ up to $1,200^{\circ} \mathrm{C}$. A sintering time of one hour was used. The topographic surface images were obtained using an atomic force microscope (Nanoscope IIIa from Digital Instruments). AFM provides high resolution surface profiles. By AFM we estimate the root mean square (RMS) roughness, from a representative grain; the mean grain size, MGS, and the shape topography. The grain size was estimated from a representative area of $10 \times 10 \mathrm{~mm}^{2}$ using a specialized software that takes as height threshold the height of larger frequency in the height spectral distribution. These spectra have a Gaussian shape in all cases. Thus, we selected the medium height to measure the grain size and we use boundary grain criteria to define the grains. In this case, grains are the zones closed and disconnected by boundaries from other regions.

$\mathrm{X}$-ray analysis of the samples was carried out with a diffractometer Rigaku 2200. Magnetic characterization was performed with a model 3001 Oxford vibrating sample magnetometer, at room temperature, in spherical samples. Corrections due to the demagnetizing field were done according to the shape of the samples. The weight percentage of $\mathrm{Ba}$ and $\mathrm{Sr}$ in several grains was estimated using an energy dispersive X-ray spectrometer, EDX, in a JEOL scanning electron microscope, SEM.

\section{RESULTS AND DISCUSSION}

AFM images for the whole set of samples $\mathrm{Ba}_{\mathrm{x}} \mathrm{Sr}_{1-\mathrm{x}} \mathrm{Fe}_{12} \mathrm{O}_{19}$ are shown in figure 1. These images show hexagonal shape in most of the grains, that is a consequence of the hexagonal structure of ferrites. Results of grain size quantification from these figures are presented in table 1 . This table allows to distingue
TABLE I.- Grain size average, RMS roughness and RMS grain roughness values for $\mathrm{Bax} \mathrm{Sr}_{1-\mathrm{x}} \mathrm{Fe}_{12} \mathrm{O}_{19}$ hexaferrites with $\mathrm{x}=0.0,0.25,0.50,0.75$ and 1.0

TABLA I.- Valores para el tamaño de grano promedio, rugosidad y rugosidad de grano, para hexaferritas de $\mathrm{Ba}_{x} \mathrm{Sr}_{1-x} \mathrm{Fe}_{12} \mathrm{O}_{19}$ con concentraciones de $x=0.0,0.25,0.50,0.75$ y 1.0

\begin{tabular}{|c|c|c|c|}
\hline $\mathrm{Ba}_{\mathrm{x}} \mathrm{Sr}_{1-\mathrm{x}} \mathrm{Fe}_{12} \mathrm{O}_{19}$ & $\begin{array}{l}\text { Grain size } \\
\qquad(\mu \mathrm{m})\end{array}$ & $\begin{array}{c}\text { RMS } \\
\text { Roughness } \\
(\mathbf{n m})\end{array}$ & $\begin{array}{c}\text { RMS } \\
\text { Grain } \\
\text { roughness } \\
(\mathrm{nm})\end{array}$ \\
\hline$x=0.0$ & 1.5 & 155.56 & -------- \\
\hline$x=0.25$ & 1.04 & 83.093 & 9.219 \\
\hline$x=0.5$ & 1.46 & 132.86 & - \\
\hline$x=0.75$ & 1.03 & 83.781 & 11.398 \\
\hline$x=1.0$ & 1.29 & 92.253 & -.-.--- \\
\hline
\end{tabular}

two kinds of grain size distribution, one narrow for the samples with $x=0.25,0.50$, and 0.75 , and one wide for the samples with just one component, barium ( $\mathrm{x}=$ $1)$ or strontium $(x=0)$. On the other hand, only small differences in the main grain size was measured among the different samples. These differences consists of a bit larger main grain size for the samples with $\mathrm{x}=0.0$, 0.50 , and 1.0. Thus, the table I shows a narrow grain size with the smallest mean grain size for the samples with $\mathrm{x}=0.25$ and 0.75 .

As presented in table I, the RMS roughness values for these samples can be related with the GSM measured. Samples with large MGS; i.e. those for

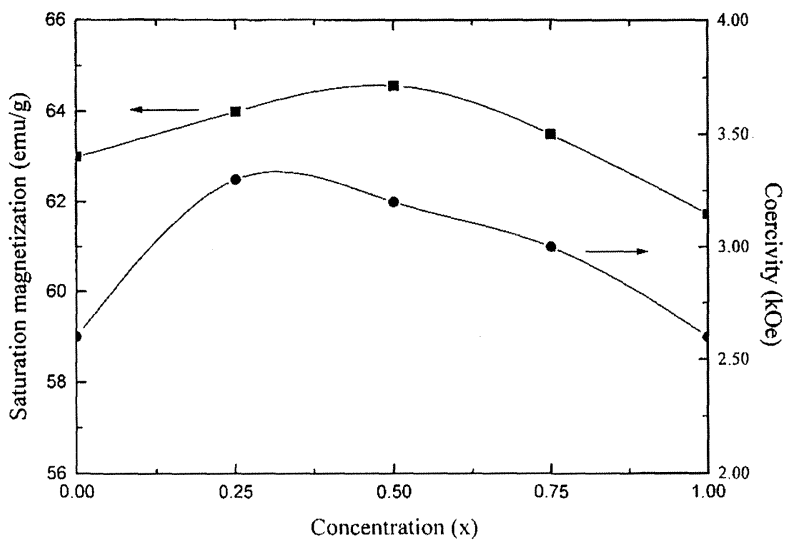

FIG. 2.- Magnetic behavior of $\mathrm{Ba}_{\mathrm{x}} \mathrm{Sr}_{1-\mathrm{x}} \mathrm{Fe}_{12} \mathrm{O}_{19}$ hexaferrites powders presintered at $1,000^{\circ} \mathrm{C}$ and sintered at $1,200^{\circ} \mathrm{C}$.

FIG. 2.- Comportamiento magnético de hexaferritas de $\mathrm{Ba}_{x} \mathrm{Sr}_{1-x} \mathrm{Fe}_{12} \mathrm{O}_{19}$, presinterizadas a $1.000^{\circ} \mathrm{C}$ y sinterizadas a $1.200^{\circ} \mathrm{C}$. 
$\mathrm{x}=0.5$ and $\mathrm{x}=0$ have a RMS roughness greater than samples with MGS smaller; i.e. those for $\mathrm{x}=1$, $\mathrm{x}=0.25$ and $\mathrm{x}=0.75$.

Figure 2 shows for this set of samples the coercivity and saturation magnetization values as a function of concentration. This figure shows that the magnetic properties are improved in the samples with two components. Therefore, for samples with $\mathrm{x}=0$ and $\mathrm{x}$ $=1$, we found poorest magnetic properties than samples with $x=0.25, x=0.50$ and $x=0.75$. Better values of magnetic properties exhibited by samples with $\mathrm{x}=0.25$ and $\mathrm{x}=0.5$ were related with a more regular grain shape and a narrow grain size distribution. For $x=0.75$ the values of magnetic properties diminish although their values are greater than those of pure samples. We can observe in AFM pictures that samples with $\mathrm{x}=0.75$ show an irregular grain shape and a larger grain roughness than the samples wiht $\mathrm{x}=0.25$ and 0.50 . This fact might be related with the lower coercivity and saturation magnetization observed. The irregular shape and grain roughness is related with the presintered temperature.

Figure 3 shows three-dimensional AFM images for the samples with $\mathrm{x}=0.75$ for presintered temperature of $800^{\circ} \mathrm{C}$ and $1,000^{\circ} \mathrm{C}$. From the figure, we can observe that the grain roughness for the sample presintered at $1,000{ }^{\circ} \mathrm{C}$ is smoother than the grain roughness for the sample presintered at $800{ }^{\circ} \mathrm{C}$. The measured RMS roughness values are $17.769 \mathrm{~nm}$ and $11.398 \mathrm{~nm}$ for the samples presintered at 800 and $1,000{ }^{\circ} \mathrm{C}$, respectively. This fact has a correspondence with the coercivity values measured in both samples of 3,250 and 3,300 Oe, respectively. The difference in these values is whitin the resolution of the magnetometer, which it is about $0.5 \%$. On the other hand, the sample with $\mathrm{x}=$ 0.25 (sample with the best magnetic values) has a RMS roughness of $9.219 \mathrm{~nm}$. From this we can conclude that it is possible a qualitative estimation of the growing grain stage using as parameters the roughness and the shape of the grain.

Grain size and homogeneity have been reported as important parameters for magnetic properties in hexaferrites (13 and 15). However, we assumme that there is a strong relationship of magnetic properties with other parameter like the dispersion of the grain size distribution and the grain roughness. It has been reported that the $\mathrm{M}$ phase in barium ferrites is reached for smaller temperatures (8) than the presintering and sintering temperatures we used. The samples have a quite homogeneus chemical composition. Little deviation from the expected stoiquiometry was determined by microanalysis with EDX. In five ramdom selected grains these diferences in strontium and barium content consisted of about 0.5 and $0.2 \%$ wt for the samples with $\mathrm{x}=0.25$ and 0.6 and $0.5 \% \mathrm{wt}$ for the sample with $\mathrm{x}=0.75$.

Figure 4 shows X-ray diffraction (XRD) patterns of samples with $x=0.25, x=0.50$, and $x=0.75$. This figure shows in all samples only the reflection corresponding to
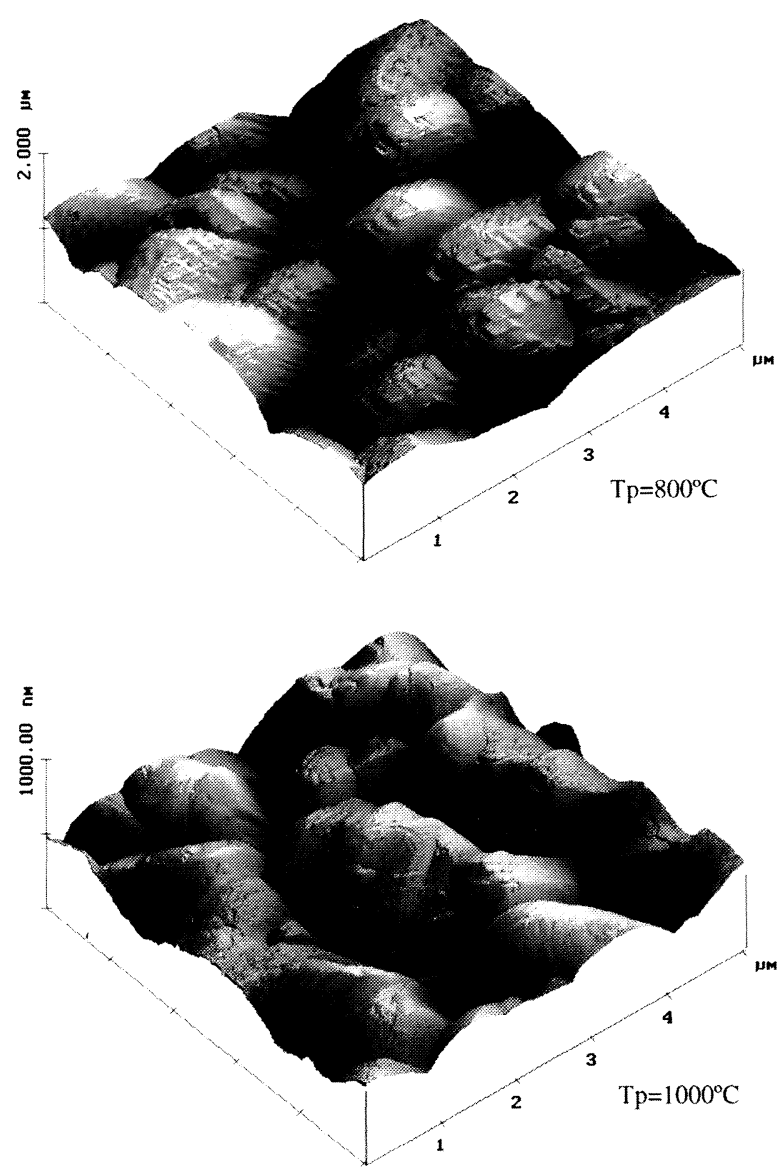

FIG. 3.- Three-dimensional AFM images of samples with $\mathrm{x}=0.75$ presintered at $800^{\circ} \mathrm{C}$ and $1,000^{\circ} \mathrm{C}$ and sintered at $1,200^{\circ} \mathrm{C}$.

FIG. 3.- Imágenes tridimensionales de MFA para muestras con una concentración de $x=0.75 y$ presinterizadas a $800^{\circ} \mathrm{C}$ y $1.000{ }^{\circ} \mathrm{C}$ y ambas sinterizadas a $1.200^{\circ} \mathrm{C}$.

the $\mathrm{BaFe}_{12} \mathrm{O}_{19}$ phase (17). Although we do not show XRD patterns obtained at each step of samples preparation, it was found that the main phase of the Mtype ferrites is obtained even at the presintering stage.

From the result we can conclude, that the principal factors determining the magnetic properties for this set of samples are the grain size distribution, the shape of the grains and the grain roughness, which are controlled by the grade mixture of $\mathrm{Ba}-\mathrm{Sr}$ and the presintered temperature. Other aspects as mean grain size and homogeneity have small changes in this case and his contribution to the magnetic values are minimum.

\section{CONCLUSIONS}

AFM is a useful technique to characterize morphological features of the grains. Three- 


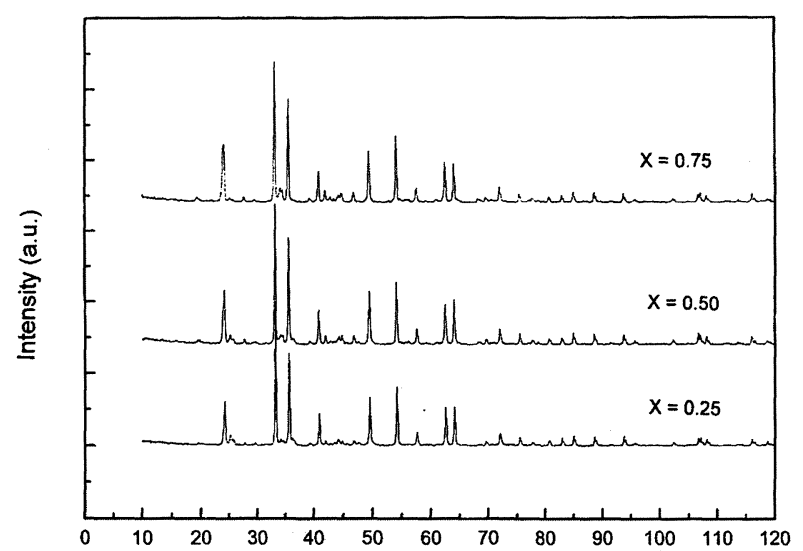

FIG. 4. - X ray difraction (XRD) patterns for samples with mixture of $\mathrm{Ba}-\mathrm{Sr}$ for $\mathrm{x}=0.25,0.50$ and 0.75 .

FIG. 4.- Patrones de rayos $X$ para muestras con mezcla de $\mathrm{Ba}-\mathrm{Sr}$ de $\mathrm{x}=0,25,0,50$ y 0,75 .

dimensional images of the surface microtopography of the samples allow to obtain information about the structural detail of the grain, which may be an important parameter related with the magnetic properties. It was observed that there is a strong relationship between the uniformity of the grain size distribution and the magnetic properties, besides of the grain size, as it has been reported.

The structural characterization of hexaferrites of Ba-Sr by means of AFM technique have shown that the shape and the grain size distribution of the samples have a strong dependence on the concentration of $\mathrm{Ba}-\mathrm{Sr}$. Furthermore, the presintering temperature regulates the shape and the structure of the grains. We conclude that the mixture $(\mathrm{Ba}-\mathrm{Sr})$ diminishes the range of particles size and the irregularity in the particles shapes of mechanically alloyed $\mathrm{Ba}$ - and Sr-hexaferrite powders (3). Therefore the magnetic parameter values were improved in $\mathrm{Ba}_{\mathrm{x}} \mathrm{Sr}_{1-\mathrm{x}} \mathrm{Fe}_{12} \mathrm{O}_{19}$ ferrites. Samples with $\mathrm{x}=0.50$ have good magnetic properties related with a narrow size distribution of large grains with uniform shape. Samples with $\mathrm{x}=0.25$ have the best magnetical properties for application as permanent magnet. These samples present regular shape grains with the smallest size. The grain size distribution is narrow and uniform. Samples with $\mathrm{x}=0.75$ present poorer magnetic properties due to a more irregular grain shape.

Another important conclusion we found was that the roughness of the grain can indicate, at least in qualitative form, the grain growing stage. This fact permits us to relate the grain shape with concentration and presintering temperature.
Furthermore an appropriate presintered temperature (about $1,000^{\circ} \mathrm{C}$ ) and a low concentration of $\mathrm{Ba}$, improve the magnetic properties of the $\mathrm{Ba}-\mathrm{Sr}$ hexaferrites prepared by the ceramic method. The resulting ferrites have better magnetic parameters than commercial ferrites prepared by conventional ceramic routes or mixed ferrites prepared by alternative methods, as the SHS method.

\section{Acknowledgments}

The authors are indebted to Lilia Narváez. This project was supported by the Consejo Nacional de Ciencia y Tecnología (CONACyT) under grants Nrs. F666-E9407 and 485100-5-2232P and FAIUASLP, Mexico.

\section{REFERENCES}

1. O. Kubo, T. IDO and H. YoKoyama, IEEE Trans. Magn.., MAG-18, 1982: 1122.

2. E. C. Stoner and E. P. Wohlfarth, Philos. Trans. R. Soc. London, Ser.A, 240, 1948: 599.

3. J. Ding, R. Street and H. Nishio, J. Magn. Magn. Mater., 164, 1996: 385.

4. K. Haneda, C. Miyakawa, and H. Kojima, $J$. Am. Ceram. Soc., 57, 1974: 354.

5. R. F. Chung-Kook, G. W. D. Speyer, J. Spratt, Appl. Phys., 73, 1993: 6266.

6. S. Castro, M. Gayoso, C. Rodriguez, J. Mira, J. Rivas, S. Paz, J. M. Greneche, J. Magn. Magn. Mater., 140, 1995: 2097.

7. J. LipKa, A. Gruskova, M. Michalikova, M. Miglierini, J. Slama, I. Toth, J. Magn. Magn. Mater., 140, 1995: 2209

8. J. Ding, D. Maurice, W. F. Miao, P. G. Mccormick, R. StreEt, J. Magn. Magn. Mater. 150, 1995: 417.

9. M. El-Hilo, H. Pfeiffer, K. O'Grady, W. SchüPPel, E. SinN, P. Görnert, M. Rösler, D. P. E. DicKSON and R. W. Chantrell, J. Magn. Magn. Mater., 129, 1994: 339.

10. M. Matsuoka, Y. Hoshi, M. NaOE and S. Yamanaka, IEEE Trans. Magn., MAG-18, 1982: 1119.

11. F. Leccabue, R. Panizzieri, G. Salviati, G. Albanese, J.L. SANChez L., J. Appl. Phys., 59, 1986: 2114.

12. W. Wolski and J. Kowalewska, Jap. J. Appl. Phys., 9, 1970: 711

13. X. Batlle, X. Obradors, M. Medarde, J. RodriguezCarbajal, M. Pernet and M. Vallet-regi, J. Magn. Magn. Mater., 124, 1993: 228.

14. I.P. Parkin, G. Elwin, L. Fernandez, Q.T. Bui, Q.A. Pankhurst, A.V. Komarov and Y.G. Morozov, $A d v$. Mater., 9, 1997: 643.

15. Y.J. Оh, I.B. Shim, H.J. Jung, J.Y. PARK, S.L. PARK, Y.R. UM, Y.J. LeE, S.W. LeE and CH.S. KIM, J. Appl. Phys., 76, 1994: 6877

16. S. Palomares-Sanchez, S. Ponce-Castañeda, F Ruiz, M. Mirabal-Garcia and J.R. Martinez, Scr. Mater., 34, 1996: 1195.

17. V. AdELSKÖLD, Ark. Kemi. Mineral. Geol., 12A, 1938: 1. 